\title{
PENGARUH METODE SOSIALISASI ORANG TUA DAN KONTROL DIRI TERHADAP KARAKTER SOPAN SANTUN REMAJA
}

\author{
Farhatil Wardah, Dwi Hastuti, dan Diah Krisnatuti \\ Institut Pertanian Bogor \\ Email: farhatilwardah2293@gmail.com
}

\begin{abstract}
Abstrak: Remaja adalah masa transisi dengan tugas perkembangan untuk mendapatkan peran sosial dan kebebasan emosional dari orang tua, tetapi remaja masih tidak dapat mengendalikan diri dengan baik. Penelitian ini menguji perbedaan jenis kelamin antara remaja laki-laki dan perempuan dalam metode sosialisasi orang tua, kontrol diri, dan pengaruhnya terhadap karakter sopan santun remaja. Penelitian ini menggunakan desain cross-sectional study. Sampel penelitian adalah siswa SMP ( $\mathrm{n}=187$, 87 laki-laki dan 100 perempuan) yang dipilih dengan teknik proporsional random sampling untuk menjawab survei menggunakan kuesioner. Data yang terkumpul dianalisis dengan SPSS 16.0. Penelitian ini menunjukkan bahwa metode sosialisasi orang tua $(\rho=0.323)$ dan kontrol diri $(\rho=0.401)$ memiliki pengaruh yang positif terhadap karakter sopan santun remaja.
\end{abstract}

Kata Kunci: sosialisasi orang tua, kontrol diri, karakter sopan santun

\section{THE INFLUENCE OF PARENTS SOCIALIZATION METHOD AND SELF CONTROL ON MANNERS CHARACTER OF ADOLESCENCE}

\begin{abstract}
Adolescent is a transition period with developmental tasks of gaining a social role and emotional freedom from parents, but adolescent still cannot control themselves well. This study examines gender differences between boys and girls in parents socialization method, self control and their influence on manners character of adolescence. This study used a cross-sectional research design. A diverse sample of junior high school students $(n=187 ; 87$ boys and 100 girls) were selected considering proportionate random sampling method to answer survey using questionnaires. The collected data was analyzed by SPSS 16.0. Findings of this study suggest that parents socialization method ( $\rho=$ $0.323)$ and self control $(\rho=0.401)$ have positive effects on manners character of adolescence.
\end{abstract}

Keyword: parents socialization, self control, manners character

\section{PENDAHULUAN}

Masa remaja merupakan masa pembentukan seperangkat nilai-nilai personal dan tujuan-tujuan yang ingin dicapai dalam kehidupan, serta direpresentasikan melalui identitas yang koheren yang akan menghasilkan kekuatan karakter berupa identitas (Peterson \& Seligman, 2004). Namun, remaja dalam perkembangannya masih belum mampu untuk menguasai fungsi-fungsi fisik maupun psikisnya (Monks et al., 2002), sehingga cenderung berperilaku menyimpang, seperti kebiasaan membolos, pelanggaran terhadap tata tertib sekolah, dan lain sebagainya (Zen, 1999).

Penelitian Hastuti, et al. (2013) menemukan bahwa remaja di Kota dan Kabupa- ten Bogor memiliki kecenderungan yang tinggi untuk terlibat dalam tawuran, bullying, pornografi, juga narkoba. Pelanggaran-pelanggaran etika seperti ini, dipandang sebagai perwujudan dari rendahnya sopan santun yang dimiliki remaja. Sementara sopan santun adalah sikap dan perilaku yang tertib sesuai dengan adat istiadat atau norma-norma yang berlaku di dalam masyarakat (Zuriah, 2007).

Semakin berkurangnya sopan santun remaja terjadi pada remaja perempuan maupun laki-laki. Namun, dalam penelitian Karina (2013) diketahui bahwa terdapat perbedaan karakter hormat santun pada remaja laki-laki dan perempuan, dengan remaja perempuan lebih memiliki karakter 
hormat santun dibandingkan remaja lakilaki. Penelitian Dewanggi (2014) juga menemukan bahwa jenis kelamin memengaruhi terbentuknya karakter anak, dan anak perempuan secara umum memiliki karakter yang lebih baik daripada anak laki-laki.

Kurangnya karakter sopan santun dapat dipengaruhi oleh rendahnya kontrol diri yang dimiliki remaja. Penelitian yang dilakukan oleh Gailiot, et al. (2012) memaparkan bahwa kontrol diri yang rendah akan menyebabkan orang melanggar norma-norma sosial dan aturan, termasuk terlibat dalam perilaku berisiko, menggunakan kata-kata yang tidak senonoh, dan mengabaikan norma yang paling dasar dan umum. Kontrol diri yang rendah membuat remaja tidak mampu memandu, mengarahkan, dan mengatur perilakunya, sehingga penting bagi remaja memiliki kontrol diri yang baik.

Pada masa remaja, anak dipengaruhi oleh beragam lingkungan, seperti rumah, sekolah, kelompok teman sebaya, organisasi, dan juga media. Namun, keluarga memegang peran fundamental dalam perkembangan remaja (Steinberg \& Silk, 2002) dan orang tua memegang peranan utama dalam sosialisasi moral (Grusec \& Kuczynski, 1997; Hoffman, 2000). Amran (Yusuf, 2006) mengartikan sosialisasi sebagai proses belajar yang membimbing anak ke arah perkembangan kepribadian sosial, sehingga dapat menjadi anggota masyarakat yang bertanggung jawab dan efektif. Orang tua dapat mengenalkan berbagai aspek kehidupan sosial, atau norma-norma kehidupan bermasyarakat, serta mendorong dan memberikan contoh kepada anak dengan beragam metode.

Akan tetapi, saat ini kesadaran orang tua sebagai pendidik moral bagi anak masih sangat rendah. Penelitian Roshita (2015) memaparkan bahwa perilaku kurang so- pan yang dilakukan oleh anak dengan teman ataupun guru, dibawa dari lingkungan rumah, karena orang tua kurang memperhatikan anak-anaknya, sibuk bekerja, lingkungan tempat tinggal yang tidak mendukung, keluarga yang broken home, dan kurangnya pendidikan orang tua. Semestinya, keluarga sebagai primary reference group mampu berperan aktif dalam membentuk dan mengembangkan tingkah laku anak, dengan menjalankan fungsi sosialisasi nilai kepada anak.

Fenomena tentang kemerosotan nilainilai moral, terutama sopan santun remaja telah menjadi lampu merah yang mendesak semua pihak untuk segera memandang penting sebuah sinergi bagi pembentukan karakter generasi muda. Berdasarkan latar belakang masalah yang telah diuraikan di atas, tujuan dari penelitian ini yaitu: (1) menganalisis hubungan karakteristik remaja, karakteristik keluarga, metode sosialisasi orang tua, dan kontrol diri dengan karakter sopan santun remaja; dan (2) menganalisis pengaruh karakteristik remaja dan keluarga, metode sosialisasi orang tua, dan kontrol diri terhadap karakter sopan santun remaja.

\section{METODE}

Penelitian ini menggunakan desain cross-sectional study dengan metode survei. Penelitian dilakukan di dua Sekolah Menengah Pertama Negeri (SMPN) di Kecamatan Cibinong, Kabupaten Bogor. Pengumpulan, pengolahan, dan analisis data dilakukan selama tujuh bulan (Maret-September 2018).

Populasi penelitian ini adalah seluruh siswa dari dua SMPN terpilih di Kecamatan Cibinong, Kabupaten Bogor tersebut. Sampel dalam penelitian ini adalah siswa yang memiliki orang tua lengkap yang di- 
pilih secara acak proporsional (proportionate random sampling).

Jenis data yang dikumpulkan dalam penelitian ini merupakan data primer yang meliputi karakteristik remaja (usia dan jenis kelamin), karakteristik keluarga (usia orang tua, lama pendidikan orang tua, pekerjaan orang tua, pendapatan orang tua, dan jumlah anggota keluarga), metode sosialisasi orang tua, kontrol diri, dan karakter sopan santun. Keseluruhan data primer dikumpulkan dengan cara mengisi kuesioner yang telah diuji validitas dan reliabilitasnya. Penggalian informasi dilakukan dengan cara self-administered menggunakan kuesioner, siswa yang menjadi contoh mengisi kuesioner sendiri dengan dipandu oleh enumerator.

Variabel metode sosialisasi orang tua diukur menggunakan kuesioner yang mengacu pada konsep Berns (1997) dan dimodifikasi oleh peneliti. Kuesioner terdiri dari 30 item pernyataan yang dibagi menjadi enam dimensi yaitu: penguatan, pengabaian, hukuman, umpan balik, belajar dengan melakukan, pemodelan, instruksi, pengaturan standar, penalaran, dan latihan kemandirian, dengan skala likert: 1 (sangat tidak sesuai), 2 (tidak sesuai), 3 (sesuai), dan 4 (sangat sesuai). Nilai cronbach alpha (ayah dan ibu) $=0.688$ dan 0.704 .

Variabel kontrol diri diukur menggunakan kuesioner yang dimodifikasi dari Self control scale (Tangney, et al. 2004). Terdiri atas 36 pernyataan, lima dimensi: performa kerja, perilaku impulsif, penyesuaian psikologis, hubungan interpersonal, dan emosi moral. Semuanya dinilai pada skala likert 4-poin, mulai dari sangat tidak sesuai (1), hingga sangat sesuai (4). Nilai cronbach alpha $=0.802$.

Variabel karakter sopan santun menggunakan kuesioner Hastuti, et al. (2013), yang terdiri atas 20 item pernyataan de- ngan lima dimensi, yaitu; menghargai diri sendiri, sopan santun terhadap orang tua, guru, sesama, dan lingkungan. Semuanya dinilai dengan skala likert: 1 (tidak pernah), 2 (jarang), 3 (sering), dan 4 (selalu). Nilai cronbach alpha $=0.795$.

Pengolahan data menggunakan $\mathrm{Mi}$ crosoft Office Excel dan analisis data menggunakan Statistical Package for Social Science (SPSS) versi 16.0. Total perolehan skor yang didapat contoh, diubah dalam bentuk indeks untuk memenuhi ketentuan uji statistik. Analisis data yang digunakan adalah statistika deskriptif (jumlah, persentase, nilai rataan, standar deviasi), uji beda T-test (menganalisis perbedaan menurut jenis kelamin remaja), uji korelasi (menganalisis hubungan antarvariabel), dan uji regresi linier berganda (menganalisis pengaruh).

\section{HASIL DAN PEMBAHASAN}

\section{Hasil}

\section{Karakteristik Remaja dan Keluarga}

Penelitian ini melibatkan 187 orang remaja yang terdiri dari 100 orang remaja perempuan dan 87 orang remaja laki-laki. Rata-rata usia remaja yang terlibat adalah 13 tahun, dengan usia termuda 12 tahun dan tertua 15 tahun. Tidak terdapat perbedaan yang signifikan antara umur remaja perempuan dan remaja laki-laki.

Hurlock (1990) mengelompokkan usia dewasa ke dalam tiga kelompok, yaitu usia dewasa awal (20-40 tahun), usia dewasa madya (41-60 tahun), dan usia dewasa akhir (>60 tahun). Sebagian besar usia ibu dan ayah berada pada kategori dewasa madya, lebih dari dua per lima ibu $(48.10 \%)$ dan $26.20 \%$ ayah tergolong pada kelompok usia dewasa awal, namun tidak terdapat ibu dan ayah yang berusia lebih dari 41 tahun. Rata-rata usia ibu (42 tahun) lebih muda dibandingkan dengan usia ayah (45 tahun). 
Orang tua remaja dalam penelitian ini memiliki tingkat pengetahuan yang cukup luas, dibuktikan dengan sebagian besar orang tua telah menuntaskan wajib belajar 12 tahun $(57.20 \%$ ayah dan $56.70 \%$ ibu), apalagi pada orang tua dengan lulusan sarjana (12.80\% ayah dan $12.30 \% \mathrm{ibu})$ dan pascasarjana $(3.70 \%$ ayah dan $2.10 \%$ ibu). Menariknya, masih terdapat orang tua yang belum menempuh pendidikan hingga tamat SD/sederajat (1.10\% ibu).

Pekerjaan orang tua cenderung beragam, dengan persentase ibu rumah tangga $(77.00 \%)$ lebih mendominasi pada jenis pekerjaan ibu, sementara jenis pekerjaan ayah yang paling dominan adalah sebagai karyawan swasta (37.95\%). Orang tua yang bekerja sebagai Pegawai Negeri Sipil (PNS) lebih didominasi ayah $(14.60 \%)$ dengan spesifiknya sebagai TNI angkatan darat, udara, atau laut. Sedangkan, untuk ibu PNS (4.70\%) lebih spesifik sebagai guru. Dengan demikian, orang tua remaja khususnya ayah cenderung memiliki pekerjaan di sektor publik, sementara ibu cenderung di sektor domestik.

Rata-rata pendapatan orang tua remaja adalah Rp 3.941.176 per bulan dengan pendapatan minimum Rp 1.000.000 dan maksimum 18.000 .000 per bulan. Apabila dilihat dari segi pendapatan, orang tua remaja tergolong mampu, karena rata-rata pendapatan sedikit lebih tinggi dari UMR Kabupaten Bogor yakni Rp 3.483.667 per bulan dengan rata-rata besar keluarga 5 orang. Hasil analisis independent samples $T$ test menunjukkan semua karakteristik keluarga antara remaja perempuan dengan remaja laki-laki tidak berbeda signifikan.

\section{Metode Sosialisasi Orang Tua}

Berns (1997) menyatakan bahwa metode sosialisasi adalah proses interaksi antara agen sosialisasi dengan anak dalam mensosialisasikan nilai-nilai kebaikan. Hasil penelitian menunjukkan bahwa orang tua dipersepsikan cukup baik dalam mensosialisasikan nilai oleh remaja. Terlihat dari 52.4 persen orang tua berada pada kategori sedang dan tidak terdapat yang terkategori rendah pada orang tua remaja laki-laki ataupun perempuan.

Metode sosialisasi yang diterapkan ayah dengan rata-rata paling tinggi adalah pemberian standar aturan terhadap sesuatu perilaku, sedangkan ibu dengan metode latihan kemandirian. Tidak terdapat perbedaan persepsi antara remaja laki-laki dan perempuan tentang metode sosialisasi yang dilakukan ayah, namun terdapat perbedaan yang signifikan metode sosialisasi ibu pada dimensi instruksi, belajar dengan melakukan, dan hukuman, yang menggambarkan bahwa remaja perempuan lebih mempersepsikan ibu menerapkan sosialisasi nilai dengan metode tersebut. Secara keseluruhan, metode sosialisasi yang dilakukan orang tua (ayah dan ibu) tidak dipersepsikan berbeda oleh remaja perempuan dan laki-laki, dengan rata-rata nilai metode sosialisasi yang dilakukan orang tua terhadap remaja laki-laki adalah 66.32 dan terhadap remaja perempuan adalah 66.28 (Tabel 1).

\section{Kontrol Diri}

Kontrol diri merupakan fungsi utama dari diri dan kunci penting untuk kesuksesan dalam hidup. Kontrol diri membuat seseorang menahan suatu respons yang dianggap negatif dan mengarahkannya kepada respons lain yang lebih baik/positif dalam segi self discipline, deliberate/nonimpulsive, healthy habits, work ethic, dan reliability (Tangney, et al., 2004).

Penelitian ini menemukan bahwa hampir seluruh remaja (95.7\%) memiliki kontrol diri terkategori sedang, dan hanya 
terdapat seorang yang terkategori rendah pada remaja laki-laki dengan rata-rata nilai 54.31 pada remaja laki-laki dan 52.99 pada remaja perempuan. Hal ini menunjukkan bahwa remaja sudah cukup baik dalam hal mengontrol diri, walaupun masih belum optimal. Kontrol diri dan semua dimensinya tidak memperlihatkan adanya perbedaan antara remaja perempuan dengan remaja laki-laki (Tabel 2).

Tabel 1. Rata-rata, Standar Deviasi, dan Uji Beda Metode Sosialisasi Orang Tua

\begin{tabular}{|c|c|c|c|}
\hline \multirow{2}{*}{ Metode Sosialisasi Orang Tua } & Laki-laki (n=87) & Perempuan $(n=100)$ & \multirow{2}{*}{$\mathrm{p}$-value } \\
\hline & Rata-rata \pm Std & Rata-rata \pm Std & \\
\hline \multicolumn{4}{|c|}{ Metode Sosialisasi Ayah } \\
\hline Penguatan & $64.36 \pm 19.40$ & $63.11 \pm 17.07$ & 0.638 \\
\hline Pengabaian & $41.37 \pm 21.54$ & $39.66 \pm 24.52$ & 0.615 \\
\hline Hukuman & $58.87 \pm 18.80$ & $61.11 \pm 17.11$ & 0.396 \\
\hline Umpan balik & $73.18 \pm 16.64$ & $74.44 \pm 13.99$ & 0.573 \\
\hline Belajar dengan melakukan & $70.62 \pm 15.80$ & $70.22 \pm 16.62$ & 0.866 \\
\hline Pemodelan & $74.20 \pm 14.22$ & $74.11 \pm 16.54$ & 0.968 \\
\hline Instruksi & $64.75 \pm 17.54$ & $59.55 \pm 18.58$ & 0.052 \\
\hline Pengaturan standar & $78.16 \pm 17.56$ & $76.66 \pm 14.85$ & 0.529 \\
\hline Penalaran & $59.77 \pm 13.04$ & $58.33 \pm 14.33$ & 0.477 \\
\hline Latihan kemandirian & $77.01 \pm 15.51$ & $77.55 \pm 16.63$ & 0.818 \\
\hline Total metode sosialisasi ayah & $66.23 \pm 7.65$ & $65.47 \pm 8.28$ & 0.521 \\
\hline \multicolumn{4}{|c|}{ Metode Sosialisasi Ibu } \\
\hline Penguatan & $70.24 \pm 15.84$ & $67.66 \pm 15.56$ & 0.264 \\
\hline Pengabaian & $47.89 \pm 22.81$ & $52.22 \pm 21.21$ & 0.181 \\
\hline Hukuman & $51.08 \pm 14.81$ & $56.11 \pm 16.44$ & $0.030^{*}$ \\
\hline Umpan balik & $74.32 \pm 15.65$ & $76.22 \pm 13.58$ & 0.377 \\
\hline Belajar dengan melakukan & $68.19 \pm 15.17$ & $73.33 \pm 14.12$ & $0.018^{*}$ \\
\hline Pemodelan & $76.11 \pm 14.43$ & $77.33 \pm 14.02$ & 0.560 \\
\hline Instruksi & $57.88 \pm 13.88$ & $64.49 \pm 18.23$ & $0.006^{* *}$ \\
\hline Pengaturan standar & $76.37 \pm 18.39$ & $74.66 \pm 13.77$ & 0.470 \\
\hline Penalaran & $56.44 \pm 11.13$ & $58.55 \pm 11.80$ & 0.213 \\
\hline Latihan kemandirian & $78.92 \pm 15.44$ & $77.00 \pm 17.24$ & 0.425 \\
\hline Total metode sosialisasi ibu & $66.41 \pm 7.26$ & $67.10 \pm 7.15$ & 0.515 \\
\hline \multicolumn{4}{|c|}{ Metode Sosialisasi Orang tua } \\
\hline Total metode sosialisasi orang tua & $66.32 \pm 6.36$ & $66.28 \pm 6.93$ & 0.973 \\
\hline
\end{tabular}

Keterangan: $\left.\alpha=95 \%{ }^{*}\right)$ signifikansi $\left.\mathrm{p}<0.05 ;{ }^{* *}\right)$ signifikansi $\mathrm{p}<0.01$

Tabel 2. Rata-rata, Standar Deviasi, dan Uji Beda Kontrol Diri Remaja

\begin{tabular}{lccc}
\hline \multirow{2}{*}{ Kontrol diri } & Laki-laki $(\mathrm{n}=87)$ & Perempuan $(\mathrm{n}=100)$ & \multirow{2}{*}{ p-value } \\
\cline { 2 - 3 } & Rata-rata \pm Std & Rata-rata \pm Std & 0.220 \\
Performa kerja & $51.99 \pm 11.11$ & $49.90 \pm 12.02$ & 0.543 \\
Perilaku impulsive & $54.83 \pm 9.47$ & $53.96 \pm 9.72$ & 0.133 \\
Penyesuaian psikologis & $57.47 \pm 11.22$ & $54.95 \pm 11.47$ & 0.419 \\
Hubungan interpersonal & $44.98 \pm 13.94$ & $43.46 \pm 11.58$ & 0.785 \\
Emosi moral & $59.00 \pm 9.88$ & $59.38 \pm 8.99$ & 0.235 \\
Total kontrol diri & $54.31 \pm 7.55$ & $52.99 \pm 7.55$ & \\
\hline
\end{tabular}

Keterangan: $\left.\mathrm{\alpha}=95 \%{ }^{*}\right)$ signifikansi $\left.\mathrm{p}<0.05 ;{ }^{* *}\right)$ signifikansi $\mathrm{p}<0.01$

\section{Karakter Sopan Santun}

Karakter berkaitan dengan pembentukan nilai kebaikan yang didefinisikan sebagai sifat-sifat yang tercermin dalam pi- kiran, perasaan, dan perilaku (Park \& Peterson, 2006). Karkater pada anak, mengalami perubahan dari tingkat what's in it for me fairness (alasan anak melakukan apa 
yang dianggap benar berhubungan dengan kepentingan dirinya) kepada tahapan interpersonal conformity di masa remaja. Pada tahap ini, anak berusaha untuk menyenangkan orang lain dengan menjadi pribadi yang baik dan berusaha memenuhi harapan orang lain agar mendapatkan pengakuan sehingga timbul kepercayaan diri (selfesteem) (Lickona, 1994).

Remaja pada penelitian ini memiliki karakter sopan santun yang sangat baik, hampir keseluruhan remaja berada pada kategori tinggi $(98.40 \%)$ dan tidak terdapat remaja yang terkategori rendah. Rata-rata nilai karakter remaja laki-laki 83.12 dan remaja perempuan 83.91 (Tabel 3). Dimensi karakter sopan santun memperlihatkan adanya perbedaan dalam menghargai diri sendiri antara remaja perempuan dan laki-laki, dengan remaja perempuan lebih dapat menghargai diri sendiri dibandingkan remaja laki-laki. Namun, secara keseluruhan tidak terdapat perbedaan yang nyata dan signifikan dalam hal karakter sopan santun.

Tabel 3. Rata-rata, Standar Deviasi, dan Uji Beda Karakter Sopan Santun Remaja

\begin{tabular}{lccc}
\hline \multirow{2}{*}{ Karakter sopan santun } & Laki-laki $(\mathrm{n}=87)$ & Perempuan $(\mathrm{n}=100)$ & \multirow{2}{*}{ p-value } \\
\cline { 2 - 3 } & Rata-rata \pm Std & Rata-rata \pm Std & \\
\hline Menghargai diri sendiri & $88.06 \pm 8.43$ & $91.14 \pm 6.16$ & $\mathbf{0 . 0 0 5}$ \\
Sopan santun terhadap orang tua & $85.31 \pm 14.32$ & $87.22 \pm 15.74$ & 0.390 \\
Sopan santun terhadap guru & $74.20 \pm 16.02$ & $72.00 \pm 16.29$ & 0.354 \\
Sopan santun terhadap sesame & $80.45 \pm 13.07$ & $81.33 \pm 10.79$ & 0.617 \\
Sopan santun terhadap lingkungan & $81.86 \pm 12.57$ & $79.11 \pm 13.42$ & 0.151 \\
Total karakter sopan santun & $83.12 \pm 8.14$ & $83.91 \pm 7.08$ & 0.477 \\
\hline
\end{tabular}

Keterangan: $\left.\alpha=95 \% ;^{*}\right)$ signifikansi $\left.p<0.05 ;{ }^{* *}\right)$ signifikansi $p<0.01$

Hubungan Karakteristik Remaja, Karakteristik Keluarga, Metode Sosialisasi Orang tua, dan Kontrol Diri dengan Karakter Sopan Santun

Tabel 4 menggambarkan bahwa tidak terdapat hubungan antara karakteristik remaja dan keluarga dengan karakter sopan santun. Variabel yang memiliki hubungan dengan karakter sopan santun adalah metode sosialisasi orang tua dan kontrol diri.

Metode sosialisasi orang tua $\left(\mathrm{r}_{1}=0.400\right.$, $\mathrm{p}<0.01)$ memiliki hubungan yang positif signifikan dengan karakter sopan santun remaja (Tabel 4). Semakin baik metode sosialisasi orang tua yang dipersepsikan remaja, maka akan semakin tinggi pula kualitas karakter sopan santun remaja. Hal ini hampir sesuai dengan penelitian Srikandi (2013) bahwa metode sosialisasi ibu memiliki hubungan positif signifikan dengan karakter hormat santun $(r=0.539, p<0.01)$. Selain itu, pernyataan tersebut juga hampir sesuai de- ngan Pasaribu (2013) bahwa metode sosialisasi ayah dan ibu berhubungan nyata dan positif dengan karakter remaja (ayah $\mathrm{r}=$ 0.406, ibu $\mathrm{r}=0.423, \mathrm{p}<0.01)$.

Tabel 4. Nilai Koefisien Korelasi Karakteristik Remaja, Karakteristik Keluarga, Metode Sosialisasi Orang Tua, dan Kontrol Diri dengan Karakter Sopan Santun

\begin{tabular}{|c|c|}
\hline Variabel & $\begin{array}{c}\text { Karakter } \\
\text { Sopan Santun }\end{array}$ \\
\hline Usia remaja & 0.040 \\
\hline Usia ibu & -0.007 \\
\hline Usia ayah & -0.059 \\
\hline Lama pendidikan ibu & 0.123 \\
\hline Lama pendidikan ayah & 0.119 \\
\hline Pendapatan keluarga & 0.045 \\
\hline Jumlah anggota keluarga & -0.067 \\
\hline Metode sosialisasi orang tua & $0.400^{* *}$ \\
\hline Kontrol diri & $0.487^{* *}$ \\
\hline
\end{tabular}

Uji hubungan pada Tabel 4 juga memperlihatkan bahwa kontrol diri berhubung- 
an positif signifikan dengan karakter sopan santun remaja $\left(\mathrm{r}_{3}=0.487, \mathrm{p}<0.01\right)$, semakin tinggi kontrol diri, maka karakter sopan santun remaja juga akan semakin meningkat. Penelitian Aroma dan Suminar (2012) memaparkan bahwa semakin tinggi skor pada kontrol diri, maka semakin rendah kecenderungan perilaku kenakalan pada remaja.

\section{Faktor-Faktor yang Memengaruhi Karak- ter Sopan Santun}

Berdasarkan hasil uji regresi linear berganda pada Tabel 5, variabel karakteristik remaja dan karakteristik keluarga tidak berpengaruh signifikan terhadap karakter sopan santun remaja. Namun, metode so- sialisasi orang tua dan kontrol diri memperlihatkan adanya pengaruh yang positif signifikan terhadap karakter sopan santun remaja $(p<0.05)$. Hal ini menunjukkan bahwa penambahan satu skor variabel metode sosialisasi orang tua akan meningkatkan skor karakter sopan santun remaja sebesar 0.323 poin dan penambahan satu skor variabel kontrol diri akan meningkatkan skor karakter sopan santun remaja sebesar 0,401 poin. Secara keseluruhan model regresi ini menjelaskan sebesar 30.1 persen variabelvariabel penelitian berpengaruh terhadap karakter sopan santun remaja sedangkan 67.9 persen lainnya dipengaruhi oleh variabel-variabel di luar penelitian.

Tabel 5. Hasil Uji Regresi Linear Berganda Variabel yang Memengaruhi Karakter Sopan Santun

\begin{tabular}{|c|c|c|c|}
\hline \multirow[b]{2}{*}{ Variabel Bebas } & \multicolumn{3}{|c|}{ Karakter Sopan Santun } \\
\hline & $\begin{array}{l}\text { Tidak terstandarisasi } \\
\text { (B) }\end{array}$ & Terstandarisasi $(\beta)$ & Sig. \\
\hline Konstanta & 39.722 & & 0.000 \\
\hline Jenis kelamin (dummy, $0=\operatorname{Pr}, 1=\mathrm{Lk}$ ) & 1.452 & 0.096 & 0.126 \\
\hline Usia remaja (tahun) & -0.276 & -0.026 & 0.673 \\
\hline Usia ayah (tahun) & -0.281 & -0.194 & 0.081 \\
\hline Usia ibu (tahun) & 0.303 & 0.189 & 0.071 \\
\hline Lama pendidikan ayah (tahun) & 0.249 & 0.092 & 0.303 \\
\hline Lama pendidikan ibu (tahun) & 0.005 & 0.002 & 0.984 \\
\hline Pendapatan keluarga (Rp/bulan) & $2.664 \mathrm{E}-7$ & 0.074 & 0.247 \\
\hline Jumlah anggota keluarga & -0.102 & -0.017 & 0.799 \\
\hline Metode sosialisasi orang tua & 0.323 & 0.284 & $0.000^{* *}$ \\
\hline Kontrol diri & 0.401 & 0.400 & $0.000 * *$ \\
\hline $\mathrm{R}^{2}$ & & & 0.338 \\
\hline Adj $R^{2}$ & & & 0.301 \\
\hline $\mathrm{F}$ & & & 9.003 \\
\hline Sig. & & & 0.000 \\
\hline
\end{tabular}

\section{Pembahasan}

Perkembangan moral anak berlangsung melalui sebuah proses yang dimulai sejak lahir dan terus berlangsung hingga dewasa. Teori perkembangan moral Lickona menyatakan bahwa moralitas individu berkembang secara perlahan dan melalui beberapa tahapan moral reasoning (kemampuan untuk memahami alasan mengapa se- suatu dianggap benar dan salah) yang akan membawa anak menuju seorang individu dengan kapasitas moral yang utuh (Lickona, 1994).

Teori pembelajaran sosial memandang bahwa perkembangan moral individu terjadi ketika individu secara aktif membangun standar perilaku melalui pengamatan dan hubungan langsung dengan orang lain 
yang ada di sekitarnya (Bandura, 1991). Anak-anak dikelilingi oleh banyak model berpengaruh, seperti orang tua di dalam keluarga, teman di kelompok sebaya dan guru di sekolah.

Keluarga memiliki peran yang sangat penting dalam membentuk individu yang berkualitas. Keluarga harus mampu mempersiapkan remaja untuk peran dan tanggung jawab sebagai bagian dari masyarakat. Oleh karena itu, isu perkembangan identitas etnis dan sosialisasi budaya menjadidominan pada masa remaja karena identitas etnis yang positif dan kepatuhan terhadap nilai-nilai kelompok budaya, etnis, atau ras ditemukan dapat meningkatkan kesejahteraan dan menjadi pelindung bagi remaja (Hughes et al., 2006).

Penelitian-penelitian sebelumnya membuktikan bahwa orang tua memegang peranan utama dalam sosialisasi nilai moral kepada anak (Grusec \& Kuczynski, 1997; Hoffman, 2000) dan sosialisasi nilai dan norma yang dilakukan oleh orang tua merupakan indikator yang signifikan terhadap nilai-nilai positif dan kompetensi sosial pada remaja (Hillaker, et al., 2008). Penelitian ini memperlihatkan bahwa metode sosialisasi orang tua memiliki pengaruh yang positif terhadap karakter sopan santun remaja ( $\rho=0.323)$, sebagaimana penelitian Pasaribu (2013) juga menemukan bahwa metode sosialisasi ibu berpengaruh positif signifikan terhadap karakter remaja. Oleh karena itu, sosialisasi dan pendidikan anak yang berkaitan dengan nilai-nilai kebaikan sangat penting dalam pembentukan karakter seorang anak.

Faktor resiko di masa remaja banyak ditemukan dan remaja memerlukan bantuan dalam menghadapi begitu banyak perubahan di saat yang bersamaan (Papalia, et al., 2008) sehingga penting bagi remaja untuk dapat memiliki kemampuan mengon- trol dan mengelola faktor-faktor perilaku sesuai dengan situasi dan kondisi dalam melakukan sosialisasi (Roosianti, 1994). Kontrol diri penting untuk dikembangkan karena individu tidak hidup sendiri melainkan bagian dari kelompok masyarakat (Acocella dan Calhoun, 1990).

Banyak penelitian yang melihat pengaruh kontrol diri terhadap perilaku negatif, seperti agresifitas, pornografi, dan lainnya (Kim, et al., 2008 dan Hardani, 2017), hal ini karena orang dengan tingkat pengendalian diri rendah cenderung bersikap impulsif, mencari aktivitas berisiko, dan egois (Arneklev, et al., 1999). Penelitian ini menunjukkan bahwa kontrol diri memiliki pengaruh terhadap perilaku positif, yaitu karakter sopan santun $(\rho=0.401)$. Kontrol diri berfungsi sebagai penghambat pembentukan perilaku negatif karena membantu remaja untuk melawan godaan dalam berbuat yang tidak sesuai dengan aturan dan norma (Ezinga, et al., 2008).

Pada penelitian ini, pengaruh terbesar dalam membentuk karakter sopan santun adalah kontrol diri remaja sehingga penting bagi remaja untuk memiliki kontrol diri yang kuat. Sebagaimana Gottfredson dan Hirschi (1990) menyampaikan dalam teori umum tentang kontrol diri atau pengendalian diri, individu dengan kontrol diri atau pengendalian diri yang rendah, memlikikarakteristik yang tidak stabil yang meningkatkan seseorang untuk melakukan tindakan-tindakan pidana atau tindakan yang menyimpang lainnya dalam kehidupan bersosial. Hasil ini searah dengan pendapat yang dikemukakan oleh Suyasa (2004) yang menyebutkan bahwa kontrol diri adalah kemampuan individu untuk menahan keinginan yang bertentangan dengan tingkah laku yang tidak sesuai dengan norma sosial yang berlaku. 


\section{PENUTUP}

Penelitian ini melibatkan 187 orang remaja yang terdiri dari 100 perempuan dan 87 laki-laki. Rata-rata usia remaja 13 tahun. Usia ibu pada rentang 30-55 tahun dengan rata-rata 42 tahun. Usia ayah pada rentang 36-58 tahun dengan rata-rata 45 tahun. Rata-rata lama pendidikan Ibu dan ayah adalah 12 tahun atau tamat pendidikan Sekolah Menengah Akhir. Pendapatan keluarga pada rentang Rp1.000.000,00Rp18.000.000,00 / bulan, dengan rata-rata Rp3.941.176,00/ bulan dengan jumlah anggota keluarga rata-rata 5 orang. Tidak terdapat perbedaan yang signifikan pada semua karakteristik remaja dan keluarga antara remaja laki-laki dan remaja perempuan.

Metode sosialisasi orang tua dan kontrol diri remaja termasuk dalam kategori sedang, sedangkan karakter sopan santun remaja terkategori tinggi, yang menunjukkan bahwa remaja memiliki karakter sopan santun yang sangat baik. Metode sosialisasi orang tua, kontrol diri, dan karakter sopan santun tidak memperlihatkan adanya perbedaan antara remaja laki-laki dan perempuan.

Karakter sopan santun dalam penelitian ini memiliki hubungan yang positif signifikan dengan metode sosialisasi orang tua dan kontrol diri, semakin baik metode sosialisasi orang tua yang dipersepsikan remaja, dan semakin tinggi kontrol diri remaja, maka kualitas karakter sopan santun akan semakin baik. Karakter sopan santun juga dipengaruhi oleh faktor metode sosialisasi orang tua dan kontrol diri. Nilai yang disosialisasikan orang tua kepada remaja dan kontrol diri yang baik yang dimiliki remaja mampu berperan dalam meningkatkan karakter sopan santun remaja.

Berdasarkan hasil yang diperoleh dari penelitian ini, saran yang dapat diberikan sebagai berikut. (1) Orang tua secara konsisten dapat menjalin kerjasama yang baik dalam melaksanakan tugas sosialisasi nilai. (2) Orang tua lebih meningkatkan kualitas sosialisasi dengan menerapkan hubungan dua arah antara orang tua-remaja. (3) Sekolah dapat memberikan materi pengembangan diri remaja terutama tentang kontrol diri. (4) Sekolah juga dapat meningkatkan peran orang tua dalam mensosialisasikan nilai-nilai karakter pada remaja dengan rutin mengadakan kelas parenting. (5) Penelitian selanjutnya, faktor lain seperti teladan guru dan media massa dapat dieksplorasi pengaruhnya terhadap karakter sopan santun remaja.

\section{DAFTAR PUSTAKA}

Acocella, J.R. \& Calhoun, J.F. (1990). Psychology of adjustment human relationship (3th ed). New York (US): McGrawHill.

Arneklev, B.J., Grasmick, H.G., \& Bursik, R.J. (1999). Evaluating the dimensionality and invariance of low selfcontrol. Journal of Quantitative Criminology, 15(3), 307-331. DOI: 10.1023/A:1007528515341.

Aroma, I.S. \& Suminar, D.R. (2012). Hubungan antara tingkat kontrol diri dengan kecenderungan perilaku kenakalan remaja. Jurnal Psikologi Pendidikan dan Perkembangan, 1(2):1-6. URL: https://docplayer.info/69683569Hubungan-antara-tingkat-kontroldiri-dengan-kecenderungan-perilaku-kenakalan-remaja.html.

Bandura, A. (1991). Sosial Cognitive theory of moral thought and action". In Kurtines, W.M. \& Gewirtz, J.L. (Eds.). Handbook of Moral Behavior and Development. Hillsdale, NJ: Erlbaum. 
Berns, R.M. (1997). Child, family, school, community socialization and support (4th ed). New York: Harcourt Brace College Publisher.

Dewanggi, M. (2014). Pengaruh Kelekatan, gaya pengasuhan, dan kualitas lingkungan pengasuhan terhadap karakter anak di perdesaan dan perkotaan. Tesis. Bogor (ID): Institut Pertanian Bogor.

Ezinga, M.A.J., Weerman, F.M., Westenberg, M., \& Bijleveld, C.C.J.H. (2008). Early adolescence and delinquency: levels of psychosocial development and self-control as an explanation of misbehaviour and delinquency. Psychology, Crime and Law. 14(4):339-356. DOI: $10.1080 / 10683160701770070$.

Gailiot, M.T., Gitter, S.A., Baker, M.D., \& Baumeister, R.F. (2012). Breaking the rules: Low trait or state self-control increases social norm violations". Psychology. 3(12):1074-1083. DOI: 10.4236/psych.2012.312159.

Gottfredson \& Hirschi. (1990). A general theory of a crime. Stanford: Stanford University Press.

Grusec, J.E. \& Kuczynski, L. (1997). Parenting and children's internalisation of values: A Handbook of contemporary theory. New York: John Wiley and Sons.

Hardani, R. (2017). Pengaruh kelekatan anak dengan orang tua, guru, teman dan kontrol diri terhadap perilaku pornografi anak SMP. Tesis. Bogor: Institut Pertanian Bogor.

Hastuti, D., Agung, S.S., \& Alfiasari, D. (2013). Kajian karakteristik remaja Desa-Kota, Sekolah Serta Keluarga untuk mengatasi perilaku anti-sosial remaja SMK di kota dan kabupaten Bogor". Prosiding Seminar Hasil-Hasil PPM IPB II, 653-667. URL: http://repository.ipb.ac.id/handle/1234567 89/72753.

Hastuti, K. \& Alfiasari, D. (2013). Hubungan karakteristik keluarga dan peer group dengan karakter dan perilaku bullying remaja. Jurnal Ilmu Keluarga dan Konsumen, 6(1), URL: http://repository.ipb.ac.id/handle/1234567 $89 / 54414$.

Hillaker, B.D., Brophy-Herb, Holly, E., Villarruel, \& Francisco, A. (2008). The contributions of parenting to social competencies and positive values in middle school youth: Positive family communication, maintaining standards, and supportive family relationships. Family Relations, 57(5), 591601. DOI: $10.1111 /$ j.1741-3729.2008.00525.x.

Hoffman, M.L. (2000). Empathy and moral development: Implications for caring and justice. New York: Cambridge University Press.

Hughes, D., Rodriguez, J., Smith, E.P., Johnson, D.J., Stevenson, H.C., \& Spicer, P. (2006). Parents' ethnic-racial socialization practices: A review of research and directions for future study. Developmental Psychology, 42(5), 747-770. DOI: 10.1037/0012-1649.42.5.747.

Hurlock, E.B. (1990). Psikologi perkembangan anak (suatu pengantar sepanjang rentang kehidupan). Jakarta: Erlangga.

Kim, E.J., Namkoong, K., Ku, T., \& Kim, S.J. (2008). The relationship between online game addiction and aggression, self-control and narcissistic personality traits. European Psychiatry, 23 (3): 
212-8. DOI: 10.1016/j.eurpsy.2007.10.010.

Lickona, T. (1994). Educating for character: How our schools can teach respect and responssibility. New York: Bantam Books.

Monks, F.J., Knoers, A.M.P., \& Hadinanto, S.R. (2002). Psikologi perkembangan: Pengantar dalam berbagai bagian. Yogyakarta (ID): Gadjah Mada University Press.

Papalia, D.E., Olds, S.W., \& Feldman, R.D. (2008). Human development (10 th Ed). Singapore: McGraw-Hill International Edition.

Park, N., \& Peterson, C. (2006). Moral competence and character strengths among adolescents: The development and validation of the values in action inventory of strengths for youth. Journal of Adolescence, 29(6), 891-910. DOI: 0.1016/j.adolescence.2006.04.011.

Pasaribu, R.M. (2013). Pengaruh gaya pengasuhan dan metode sosialisasi orang tua terhadap karakter jujur dan tanggung jawab siswa SMA di Kota Bogor. Tesis. Bogor: Institut Pertanian Bogor.

Peterson, C.\& Seligman, M.E.P. (2004). Character strengths and virtues: A handbook and classification. New York and London(US): Oxford University Press.

Roosianti, W. (1994). Hubungan antara Pemantauan diri dan popularitas dengan pengungkapan diri pada remaja. Skripsi. Yogyakarta: Fakultas Psikologi UGM.

Roshita, I. (2015). Upaya meningkatkan perilaku sopan santun melalui layanan bimbingan kelompok dengan teknik sosiodrama. Jurnal Penelitian Tindakan Bimbingan dan Konseling. 1(1), 64-70. URL: https://i-rpp.com/index.php/jptbk/article/view/223.

Srikandi, P.D. (2013). Hubungan stimulasi psikososial dan metode sosialisasi dengan karakter disiplin dan hormat santun remaja pada keluarga bercerai. Skripsi. Bogor: Institut Pertanian Bogor.

Steinberg, L. \& Silk. (2002). Adolescence. New York: Mc Grew-Hill Inc.

Suyasa. (2004). Pengaruh kontrol diri terhadap pembelian implusif. Jurnal Pronosiy, 118-122.

Tangney, J., Baumeister, R.F., \& Boone, A.L. (2004). High self-control predicts good adjustment, less pathology, better grades, and interpersonal success. Journal of personality. 72(2), 271-324. DOI: 0.1111/j.0022-3506.2004.00263.x.

Yusuf, S. (2006). Psikologi perkembangan anak dan remaja. Bandung: PT. Remaja Rosdakarya.

Zen M. (1999). Faktor-faktor determinatif perilaku menyimpang di kalangan remaja. Mimbar Pendidikan, 18(2), 39-47. URL: https:// docplayer.info/31451651-Faktor-faktor-determinatif-perilaku-menyimpang-di-kalangan-remaja.html.

Zuriah, N. (2007). Pendidikan moral dan budi pekerti dalam perspektif perubahan. Jakarta (ID): PT. Bumi Aksara. 